\title{
Land-Sea Contrast in the Earth Radiation Budget
}

\author{
By Isao Kubota* and Hiroko Imai** \\ *Meteorological Satellite Center \\ **Meteorological Research Institute \\ (Manuscript received 17 December 1985, in revised form 17 September 1986)
}

\begin{abstract}
In order to make clear the difference between the earth's radiation budget over land and over sea, three components of the budget measured by the wide field of view sensors aboard NIMBUS 7 were analyzed for the period during November 1978 to October 1979.

In each of the absorbed solar radiation and the emitted terrestrial radiation, it is confirmed that the zonal average over sea is about $40 \mathrm{~W} / \mathrm{m}^{2}$ larger than over land covering the latitudinal range of 40 degrees around the solar declination. It is interpreted because the clear sky albedo over sea is about half of that over land and also the cloud amount over sea is about $13 \%$ less than that over land in the equatorial zone.

In the absorbed solar radiation, it is found that in summer the zonal average over sea is about 15 $\mathrm{W} / \mathrm{m}^{2}$ smaller than that over land covering the latitudinal range of 30 degrees centered $60 \mathrm{~N}$ or $60 \mathrm{~S}$. It is estimated because in the latitude of summer the cloud amount over sea is so larger than over land as to cancel the clear sky albedo effect though clear sky albedo over sea is about half of that over land.

In the emitted terrestrial radiation, it is also found that the minimum zone of it associated with ITCZ is lower over land than over sea, and the maximum zones of it associated with the subtropical high pressure zones are larger over land than over sea. This strangely means that the direct circulation over land looks like more active than over sea in the equatorial zone.
\end{abstract}

\section{Introduction}

The earth radiation budget (ERB) consists of three components; absorbed solar radiative flux $S \downarrow$, emitted terrestrial radiative flux $T \uparrow$ and net, total radiative flux $N \downarrow$. And they have a relationship

$$
N \downarrow=S \downarrow-T \uparrow
$$

where an arrow in the superscript indicates positive direction of the component. $S \downarrow$ is shortwave energy input to the earth and $T \uparrow$ is longwave energy output from the earth. $N \downarrow$ is the heat source or sink which warms or cools the earth and also drives general circulation of the atmosphere and the ocean. Therefore to analyze ERB is basically important in order to investigate the mechanism of climatic change in the planetary scale, for example, generation of the ice age, effect of volcanic eruption to climate, effect of change in solar constant to cli- mate, warming with increasing of $\mathrm{CO}_{2}$ and effect of cloud to climate.

The global ERB observation has been performed by polar orbiting, meteorological satellites. Raschke and Vonder Haar (1973), Gruber (1977), Gruber and Winston (1978) and Jacobowitz, Smith, Howell and Nagle (1979) analyzed global distributions in the annual mean and seasonal variations in the zonal mean of ERB. Stephens, Campbell and Vonder Haar (1981) analyzed seasonal variations of the global distribution of ERB. Warren and Thompson (1983) discussed generation of climatological minimum in the tropical outgoing infrared radiation. The latitudinal variation of ERB components are much predominant than the longitudinal variation. Therefore the researches on ERB has been focused in the latitudinal variation than the longitudinal variation.

Examining distributions of ERB components 
plained by Tighe and Shen (1983) and Jacobowitz et al. (1984a). Measurements by WFOV and these by NFOV are compared and examined by Jacobowitz et al. (1984b).

3. Latitude-time variations of the zonal averages in $S \downarrow, N \downarrow$ and $T \uparrow$ each over sea and over land

In the world grid of approximately equal area, if a grid area is occupied over 50\% by land (sea), the grid is defined as a land (sea) grid. $S \downarrow, T \uparrow$ and $N \downarrow$ are zonally averaged for land and for sea area of the grid. Hereafter the zonal average in whole latitudinal zone is expressed by ${ }^{-}$, that

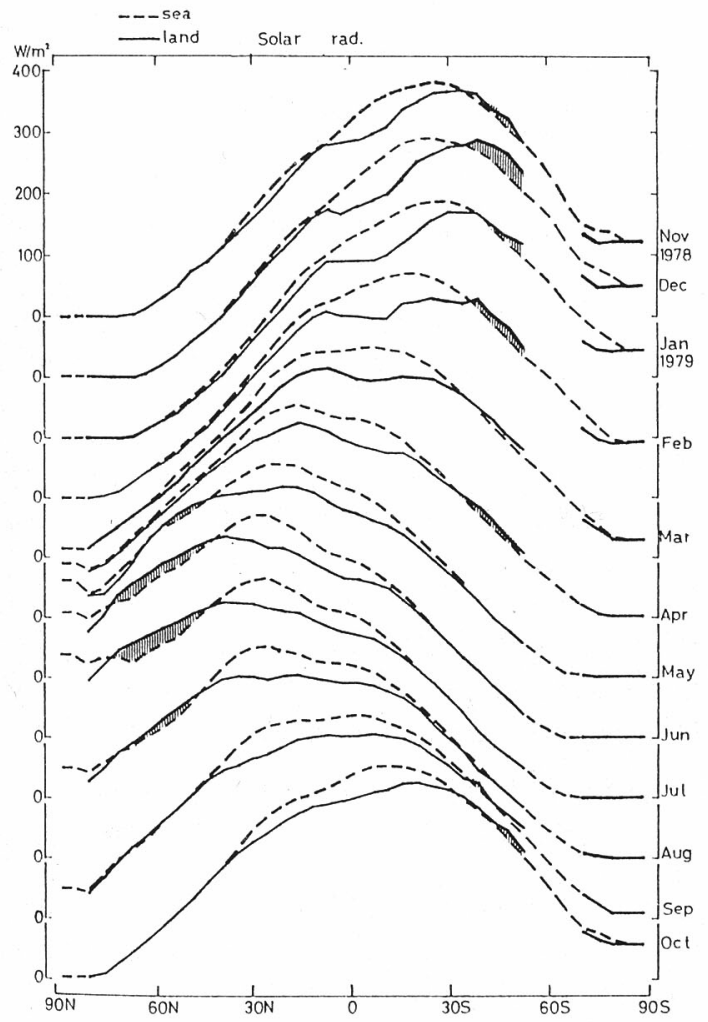

Fig. 1. Annual variation of latitudinal distributions in absorbed solar radiative flux $S \downarrow$. The ordinate is marked with $400,300,000,100$ and $0 \mathrm{~W} / \mathrm{m}^{2}$ only for $S \downarrow$ of November 1978 , and with only $0 \mathrm{~W} / \mathrm{m}^{2}$ for $S \downarrow$ of other months. Solid curves are for zonal average over land and broken curves for zonal average over sea. Zonal averages over land in the arctic area northern than $81 \mathrm{~N}$ and in the vicinity to $60 \mathrm{~S}$ between 54.0S and $67.5 \mathrm{~S}$ are broken off because there is no land. An area, where the average over land is greater than the average over sea, is shaded. in sea area by ${ }^{-s}$ and that in land area by ${ }^{-1}$.

Latitude-time variations of $\overline{S \downarrow}^{1}$ and $\overline{S \downarrow}^{s}$ are shown in Fig. 1. The maximum of $\overline{S \downarrow}^{s}$ occurs near the solar declination. In the seasons including vernal equinox or autumn equinox when the solar declination passes the equator, the maximum of $\overline{S \downarrow}^{1}$ does not necessarily locates near the equator, because the active convection increases the planetary albedo particularly over land.

In the latitudes where $\overline{S \downarrow}$ is large (for example, where $\overline{S \downarrow}{ }^{s}>$ about $\left.300 \mathrm{~W} / \mathrm{m}^{2}\right), \overline{S \downarrow}^{s}$ surpasses $\overline{S \downarrow}^{1}$ covering the latitudinal range of about $70^{\circ}$. The latitudinal range where $\overline{S \downarrow^{3}}$ is larger than $\overline{S \downarrow}^{1}$ by $40 \mathrm{~W} / \mathrm{m}^{2}$ is about $40^{\circ}$.

In the vicinity of $60 \mathrm{~N}$ or $60 \mathrm{~S}$, in the summer hemisphere, $\overline{S \downarrow}^{1}$ surpasses $\overline{S \downarrow^{\natural}}$ by $15 \mathrm{~W} / \mathrm{m}^{2}$ covering the latitudinal range of about $30^{\circ}$.

Fig. 2 shows latitude-time variation of $\overline{N \downarrow}^{1}$ and $\overline{N \downarrow}$ s. The figure shows that as far as the difference between $\overline{N \downarrow}^{1}$ and $\overline{N \downarrow}^{s}$ the feature is almost the same as the difference between $\bar{S}^{1}$ and $\overline{S \downarrow}$.

In the vicinity of $60 \mathrm{~N}$ or $60 \mathrm{~S} \overline{N \downarrow}^{1}$ is larger than $\overline{N \downarrow}$ s all the year round, since in summer $\overline{S \downarrow}^{1}$ is larger than $\overline{S \downarrow}^{s}$ and in other seasons $\bar{T}^{1}$ is weaker than $\overline{T \uparrow^{s}}$.

Fig. 3 shows latitude-time variation of $\overline{T \uparrow}^{1}$ and $\overline{T \uparrow^{s}}$. A common feature of $\overline{T \uparrow}^{1}$ and $\overline{T \uparrow}^{s}$ is that there is one minimum near the equator and two maximums at the subtropical zones of each hemisphere.

These maximums of $\overline{T \uparrow}$ may be associated with the sinking motion and the minimum of $\overline{T \uparrow}$ the rising motion of the direct circulation. Or the maximums represent the subtropical high pressure zones and the minimum the intertropical convergence zone (ITCZ). Fig. 4 shows climatological distribution of total cloud amount for January and July presented by Berlyand and Strokina (1980). Fig. 5 shows latitude-time variation of climatological total cloud amount averaged over sea and over land $\left(\bar{C}^{s}, \bar{C}^{1}\right)$ presented by Berlyand, Strokina and Greshnikova (1980). These figures and other climatological total cloud distributions presented by Hughes (1984) confirm the above view.

The minimum of $\overline{T \uparrow}^{1}$ tends to be lower than the minimum of $\overline{T \uparrow^{s}}$ and the both maximums 


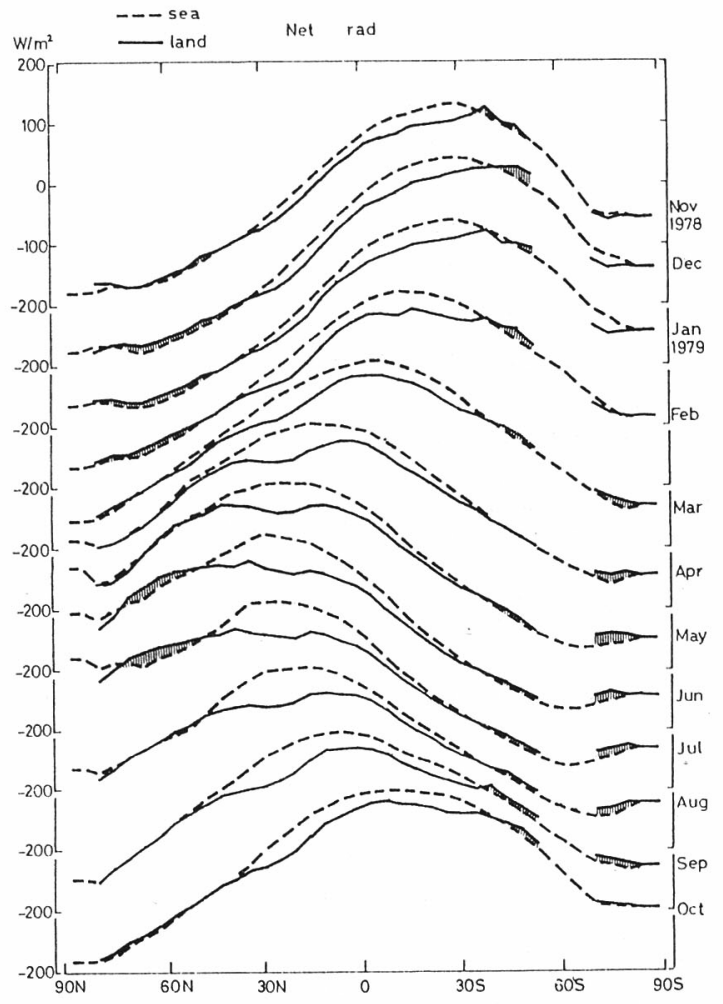

Fig. 2. As Fig. 1 except for net, total radiative flux $N \downarrow$. The ordinate is marked with $200,100,0,-100$ and $-200 \mathrm{~W} / \mathrm{m}^{2}$ only for $N \downarrow$ of November 1978 , and with only $-200 \mathrm{~W} / \mathrm{m}^{2}$ for $N \downarrow$ of other months.

of $\overline{T \uparrow}^{1}$ tend to be larger than $\overline{T \uparrow^{s}}$. The amplitude of $\overline{T \uparrow}{ }^{1}$ between the maximum and the minimum tends to be larger than that of $\overline{T \uparrow}^{s}$. These facts strangely mean that the direct circulation over land looks like more active than over sea in the equatorial zone.

The latitude where $\overline{S \downarrow}$ or $\overline{N \downarrow}$ has the maximum nearly agrees with the solar declination, which is ranged in the tropics between $23 \mathrm{~N}$ and $23 \mathrm{~S}$. But the latitude where $\overline{T \uparrow}$ has the minimum varies annually only in the equatorial zone between about $10 \mathrm{~N}$ and $10 \mathrm{~S}$.

\section{Causes of land-sea contrast of $S \downarrow$}

$S \downarrow$ is represented as follows

$$
S \downarrow=I(1-\alpha)
$$

where $\mathrm{I}$ is the extra terrestral solar irradiance in $\mathrm{W} / \mathrm{m}^{2}$ and $\alpha$ is the planetary albedo. $\alpha$ is expressed as follows

$$
\alpha=\alpha_{c} A_{c}+\alpha_{s}\left(1-A_{c}\right)
$$

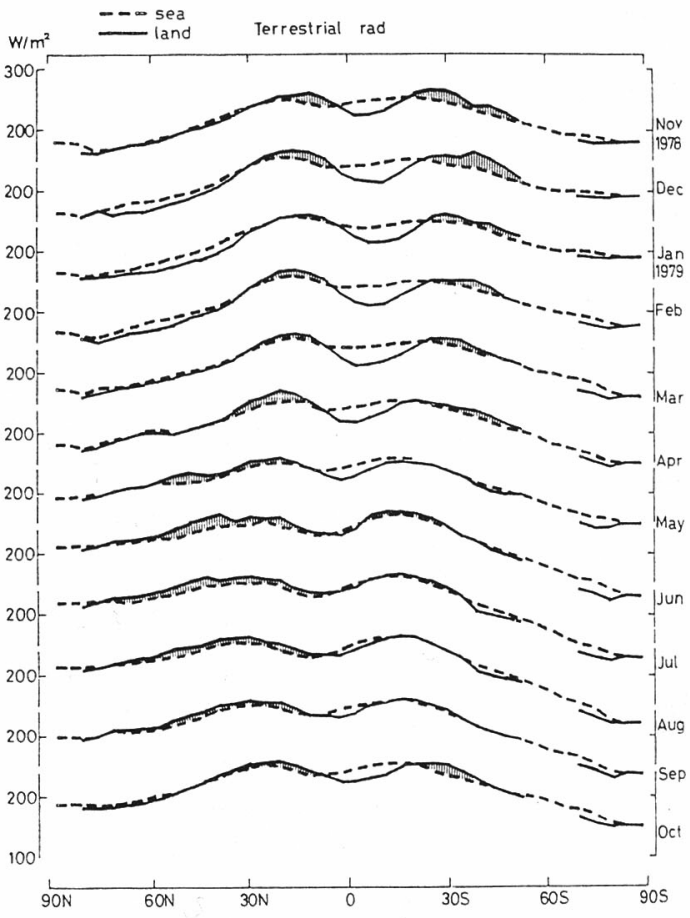

Fig. 3. As Fig. 1 except for emitted terrestrial radiative flux $T \uparrow$. The ordinate is marked with 300 and 200 $\mathrm{W} / \mathrm{m}^{2}$ only for $T \uparrow$ of November 1978 , and with only $200 \mathrm{~W} / \mathrm{m}^{2}$ for $T \uparrow$ of other months.

which was proposed by Cess (1976). Here $A_{c}$ denotes cloud amount, $\alpha_{c}$ cloud albedo and $\alpha_{s}$ clear-sky albedo.

The excess of $\overline{S \downarrow}^{s}$ to $\overline{S \downarrow}^{1}$ may be attributed to the excess of $\bar{\alpha}_{s}^{1}$ to $\bar{\alpha}_{s}^{s}$ and the difference between $\bar{A}_{c}^{1}$ and $\bar{A}_{c}^{s}$. Eliminating $\alpha$ from (3) and (4), and differenciating the result derives

$$
\Delta S \downarrow=-I\left[\left(\alpha_{c}-\alpha_{s}\right) \Delta A_{c}+\left(1-A_{c}\right) \Delta \alpha_{s}\right]
$$

where $\Delta x$ denotes the deviation of $x$ over sea from over land, and $\Delta \alpha_{c}$ is supposed to be zero. Also (5) leads following equation for $\Delta A_{c}$

$$
\Delta A_{c}=-\left[\Delta S \downarrow / I+\left(1-A_{c}\right) \Delta \alpha_{s}\right] /\left(\alpha_{c}-\alpha_{s}\right)
$$

i. Causes of $40 \mathrm{~W} / \mathrm{m}^{2}$ excess of $\overline{S \downarrow}^{s}$ to $\overline{S \downarrow}^{1}$ in the vicinity of the solar declination

In the vicinity of the solar declination, referring Fig. 6

$$
\mathrm{I} \sim 450 \mathrm{~W} / \mathrm{m}^{2}
$$



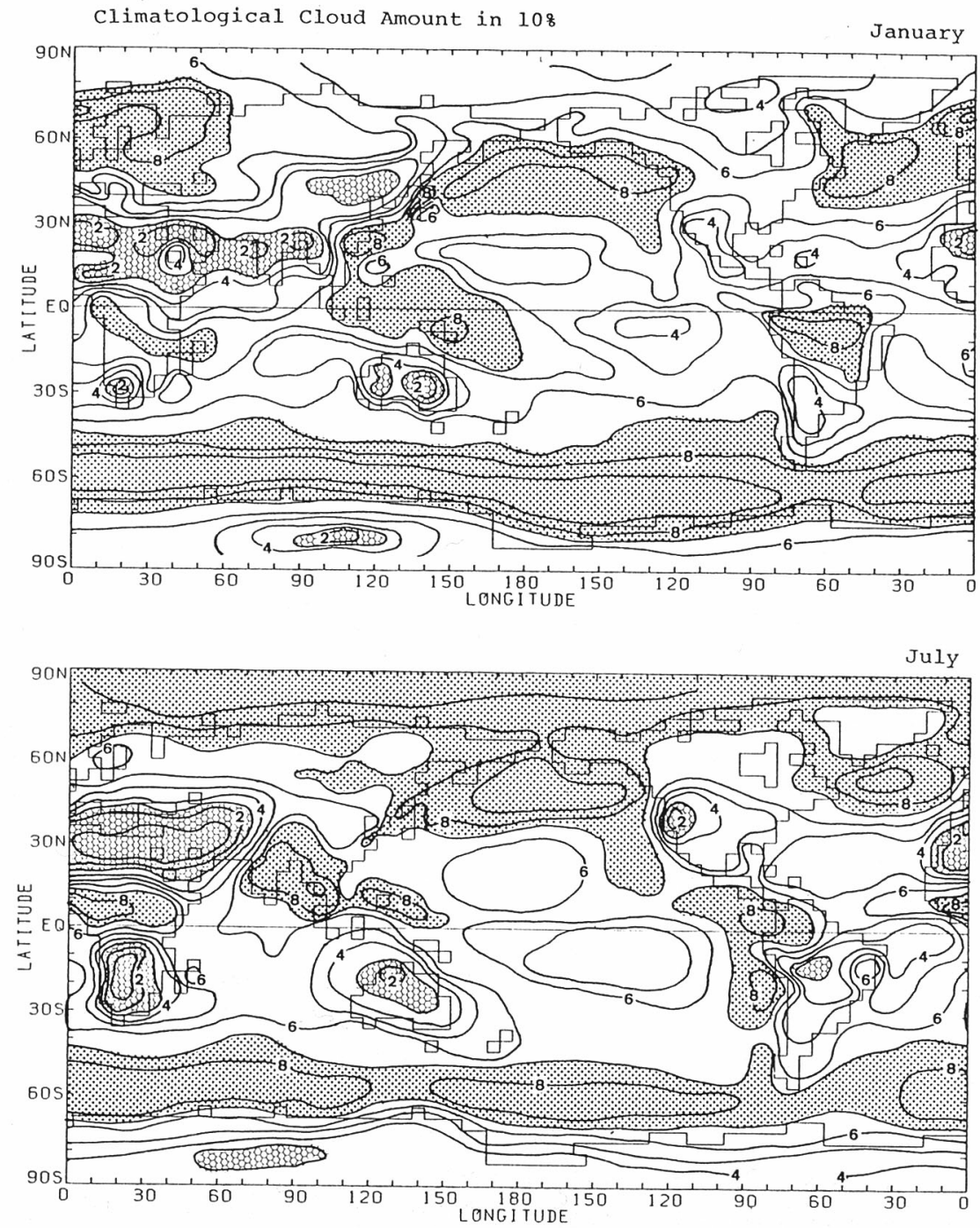

Fig. 4. Global distributions of total cloud amount for January and July compiled by Berlyand and Strokina (1980). Unit indicates 10\%.

Representative cloud amount is, referring Fig. 5,

$$
A_{c} \sim \bar{A}_{c} \sim 0.6
$$

Concerning $\alpha_{c}$ and $\alpha_{s}$, referring Fig. 7 , since cosz $\sim 0.66$ ( $z$ denotes solar zenith angle and cosz $=\frac{1}{2 \tau} \int_{-\tau}^{\tau} \cos z d t=\frac{I}{I_{0}\left(\mathrm{r}_{0} / \mathrm{r}\right)} \frac{\pi}{\tau} \sim \mathrm{I} \times 2 / \mathrm{I}_{0}=$ $\left(450 \mathrm{~W} / \mathrm{m}^{2}\right) \times 2 /\left(1370 \mathrm{~W} / \mathrm{m}^{2}\right)=0.66$, where $\tau$ denotes half length of a day), we get

$$
\alpha_{c} \sim \bar{\alpha}_{c} \sim 0.55
$$

$$
\left.\begin{array}{l}
\bar{\alpha}_{s}^{1} \sim 0.22 \\
\bar{\alpha}_{s}^{s} \sim 0.12 \\
\alpha_{s} \sim \bar{\alpha}_{s} \sim\left(\bar{\alpha}_{s}^{s}+\bar{\alpha}_{s}^{1}\right) / 2=0.17 \\
\Delta \alpha_{s}=\bar{\alpha}_{s}^{s}-\bar{\alpha}_{s}^{1}=-0.10
\end{array}\right\}
$$

Supposing $\Delta A_{c} \sim 0$, and substituting (7), (8), (9) and (10) into (5), we get

$$
\Delta S \downarrow \sim 18 \mathrm{~W} / \mathrm{m}^{2}
$$

This means that the excess of $\bar{\alpha}_{s}^{1}$ to $\bar{\alpha}_{s}^{s}$ contributes to only half of the excess of $\overline{S \downarrow}$ to $\overline{S \downarrow} 1$

Substituting (7), (8), (9), (10) and 


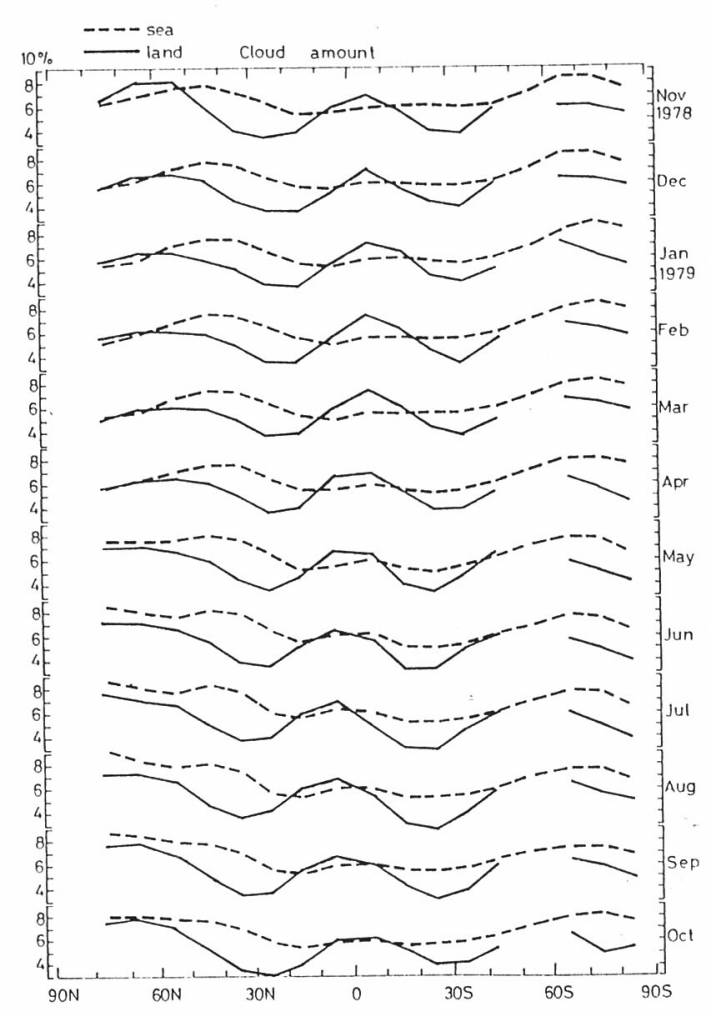

Fig. 5. Latitude-time variation of zonally averaged cloud amount over land and sea compiled by Berlyand, Strokina and Greshnikova (1980).

$$
\Delta S \downarrow \sim 40 \mathrm{~W} / \mathrm{m}^{2}
$$

into (6), we get

$$
\Delta A_{c} \sim-0.13
$$

This means that the excess of $\overline{S \downarrow^{s}}$ to $\overline{S \downarrow}^{1}$ around the solar declination is attributed to that $\bar{\alpha}_{\frac{1}{s}}^{1}$ is twice as large as $\bar{\alpha}_{s}^{s}$ and $\bar{A}_{c}^{1}$ is $13 \%$ larger than $\bar{A}_{c}^{s}$. According to the climatological cloud distributions shown in Fig. 4 and 5 , it is certain that the cloud amount over the ITCZ is larger over land than over sea in the equatorial zone. But it is not true for the subtropical high pressure zone in the summer hemisphere, that is, the $20-30 \mathrm{~N}$ zone in the northern hemispheric summer and the 20-30S zone in the southern hemispheric summer.

Main deserts distribute in the subtropical high pressure zones. The clear-sky albedo over the desert is larger than that over the entirely averaged land. According Ohring and Gruber (1983), the clear-sky albedo over the desert is 25 to $35 \%$. If we suppose $\bar{\alpha}_{5}^{1} \sim 0.30$ in (10), we get $\Delta A_{c} \sim 0.06$. This means that in the sub-

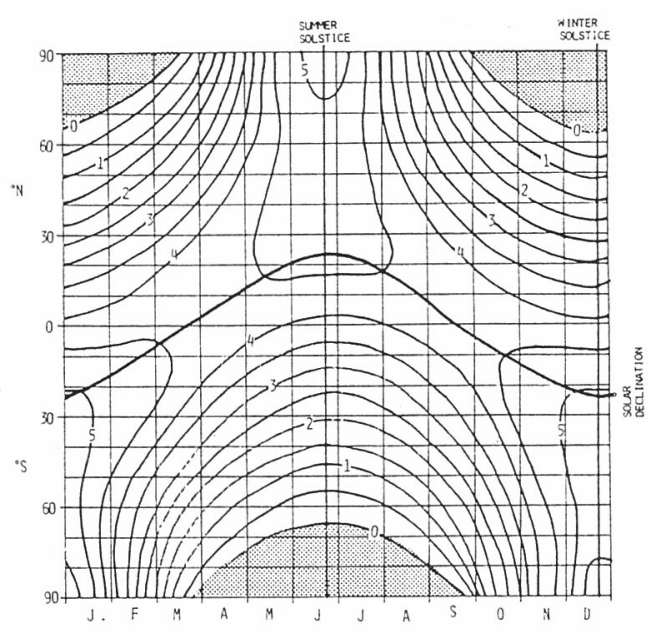

Fig. 6. Latitude-time variation of extra terrestrial solar radiative flux $\mathrm{I}$. Unit of numerals is $100 \mathrm{~W} / \mathrm{m}^{2}$. I is about $450 \mathrm{~W} / \mathrm{m}^{2}$ in the vicinity of the solar declination. $I$ is also about $450 \mathrm{~W} / \mathrm{m}^{2}$ in the vicinity of $60 \mathrm{~N}$ or $60 \mathrm{~S}$ in summer.

tropical high pressure zones, the cause of the excess of $\overline{S \downarrow}_{\downarrow}^{s}$ to $\overline{S \downarrow}^{1}$ may be attributed to only the excess of $\bar{\alpha}_{s}^{1}$ to $\bar{\alpha}_{s}^{s}$.

ii. Causes of $15 \mathrm{~W} / \mathrm{m}^{2}$ excess of $\overline{S \downarrow}^{1}$ to $\overline{S \downarrow^{\mathrm{s}}}$ near $60 \mathrm{~N}$ or $60 \mathrm{~S}$ in the summer hemisphere

As $\cos z \sim 0.66$ referring Fig. 6 ,

$A_{c} \sim \bar{A}_{c}: \sim 0.7 \quad$ (after Fig. 5)

$\mathrm{I} \sim 450 \mathrm{~W} / \mathrm{m}^{2} \quad$ (after Fig. 6)

$\Delta S \downarrow \sim-15 \mathrm{~W} / \mathrm{m}^{2} \quad$ (after Fig. 1)

$\alpha_{c} \sim \bar{\alpha}_{c} \sim 0.55 \quad$ (after Fig. 7)

$\bar{\alpha}_{s}^{1} \sim 0.22$

(after Fig. 7)

$\bar{\alpha}_{s}^{s} \sim 0.12$

(after Fig. 7)

$\alpha_{s} \sim \bar{\alpha}_{s} \sim\left(\bar{\alpha}_{s}^{s}+\bar{\alpha}_{s}^{1}\right) / 2=0.17$

$\Delta \alpha_{s}=\bar{\alpha}_{s}^{s}-\bar{\alpha}_{i}^{1}=-0.10$

Fis

Substituting (14), (15), (16), (17) and (18) into (6), we get

$$
\Delta A_{c} \sim 0.17
$$

This means that the excess of $\overline{S \downarrow}^{1}$ to $\overline{S \downarrow}^{s}$ around $60 \mathrm{~N}$ or $60 \mathrm{~S}$ in the summer hemisphere is attributed to about $17 \%$ excess of $\bar{C}^{s}$ to $\bar{C}^{1}$ in spite of the double of $\bar{\alpha}_{s}^{1}$ to $\bar{\alpha}_{s}^{s}$. Fig. 4 and 5 support this result.

\section{Conclusion and an interesting theme}

\section{i. Conclusion}

a. Both absorbed solar radiation $(S \downarrow)$ and net, total radiation $(N \downarrow)$ are about $40 \mathrm{~W} / \mathrm{m}^{2}$ greater or

ti

$S$

bu

or

$\mathrm{ac}$

ne

gr

60

th

ov

or

do

ra

ha

A 


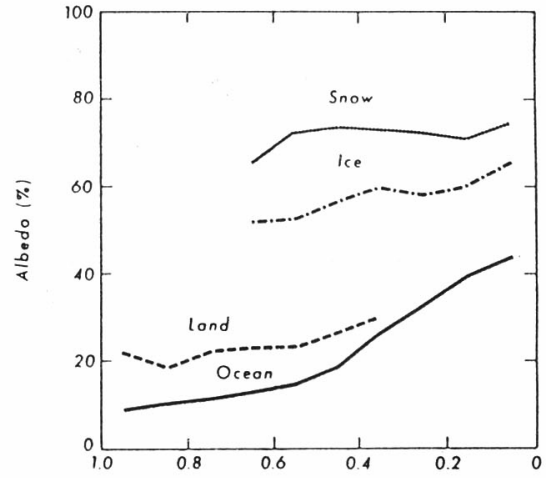

(a) Cosine Solor Zenith Angle

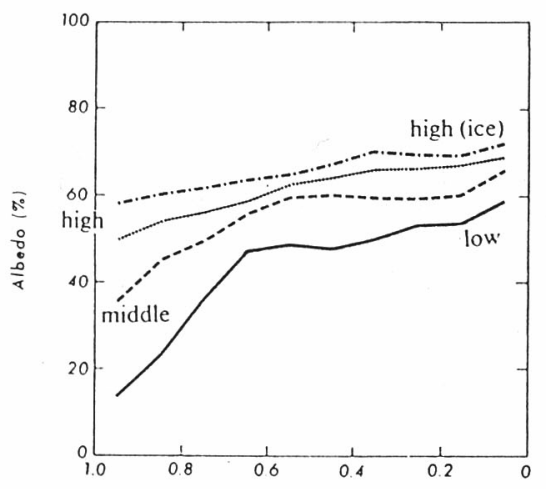

(b) Cosine Solar Zenith Angle

Fig. 7. Relations between cosine (solar zenith angle) and clear-sky albedo $\alpha_{s}$ (a), or cloud albedo $\alpha_{c}$ (b) (Ohring and Gruber (1983)).

over sea than over land around the solar declination. An estimation showed that this excess of $S \downarrow$ or $N \downarrow$ over sea to $S \downarrow$ or $N \downarrow$ over land is attributed not only to about double clear-sky albedo over land to over sea but to $13 \%$ larger cloud amount over land than over sea in the equatorial zone.

b. Both absorbed solar radiation $(S \downarrow)$ and net, total radiation $(N \downarrow)$ are about $15 \mathrm{~W} / \mathrm{m}^{2}$ greater over land than over sea around $60 \mathrm{~N}$ or $60 \mathrm{~S}$ in the summer hemisphere. It was estimated that this excess of $S \downarrow$ or $N \downarrow$ over land to $S \downarrow$ or $N \downarrow$ over sea is attributed to $17 \%$ larger cloud amount over sea than that over land, in spite of about double clear-sky albedo over land to over sea.

c. The minimum zone of emitted terrestrial radiation $(T \uparrow)$ associated with ITCZ tends to have the smaller value over land than over sea. And each maximum zone of emitted terrestrial radiation ( $T \uparrow)$ associated with the subtropical high pressure tends to have the larger value over land than over sea. These facts shows that the direct circulation over land looks like more active than that over sea.

The seasonal variation of the latitude of the minimum zone is much smaller than that of the solar declination.

\section{ii. An interesting guess}

If it is confirmed that $\overline{N \downarrow}^{s}$ is about $40 \mathrm{~W} / \mathrm{m}^{2}$ larger than $\overline{N \downarrow}^{1}$ covering the $40^{\circ}$ latitudinal range around the solar declination, it makes us following interesting guess.

In the present age the apogee of the sun is in summer and the perigee is in winter. Difference between $\mathrm{I}$ at the apogee and perigee is $7 \%$ of $\mathrm{I}$.

The period of the precession of the equinoxes is about 26,000 years. About 13,000 years ago the apogee of the sun was in winter and the perigee was in summer. The land area is 2.5 times larger in the northern hemisphere than that in the southern hemisphere. Therefore about 13,000 years ago the energy input must be smaller than that in the present age. And the energy output must be smaller than that in the present age to balance the energy input. Lower temperature of the earth's surface omits smaller energy output.

To estimate the energy input in aobut 13,000 years ago and to investigate the effect to the energy output and the temperature of the earth's surface is the interesting next theme.

\section{Acknowledgment}

The authors express their gratitude to NOAA, NASA and Dr. R. Schiffer that offered Japan Meteorological Research Institute the ERB. MATRIX and ERB.SEFDT data sets for the period from November 1978 to October 1979. Also they thank Prof. T. Berlyand who sent us the cloud data and accepted the presentation of Fig. 4 and 5 in this paper.

\section{References}

Berlyand, T.G., L.A. Strokina and L.E. Greshnikova, 1980: Zonal cloud distribution on the earth. Meteor. Gidrol., 3, 15-23.

and - 1980: Global distribution of total cloud amount. Leningrad, Gidrometeoizdat, 
pp. 71.

Campbell, G.G. and T.H. Vonder Haar, 1980a: An analysis of two years of NIMBUS 6 earth radiation budget observations: July 1975 to June 1977. Colorado State University, Atmospheric Science Paper, 320, pp. 83. and

1980b: Climatology of radiation budget measurement from satellite. Colorado State University, Atmospheric Science Paper, 323, pp. 73.

Cess, R.D., 1976: Climatic change, an appraisal of atmospheric feedback mechanisms employing zonal climatology. J. Atmos. Sci., 33, 1831-1843.

Gruber, A., 1977: Determination of the earth-atmosphere radiation budget from NOAA satellite data. NOAA Technical Report NESS 76, pp. 28. and J.S. Winston, 1978: Earth-atmosphere radiative heating based on NOAA scanning radiometer measurements. Bull. Amer. Meteor. Soc., 59, $1570-1573$.

Hartmann, D. and D.A. Short, 1980: On the use of earth radiation budget statistics for studies of clouds and climate. J. Atmos. Sci., 37, 1233-1250.

Henderson-Sellers, A., 1984: The earth's radiation budget and clouds. Satellite sensing of a cloudy atmosphere, Taylor \& Francis, pp. 340, 91-122.

Hughes, H.A., 1984: Global cloud climatologies, A historical review. J. Climate and Applied Met., 23, $724-751$.

Jacobowitz, H., W.L. Smith, H.B. Howell, F.W. Nagle and J.R. Hickey, 1979: The first 18 months of planetary radiation budget measurements from Nimbus 6 ERB experiment. J. Atmos. Sci., 36, $501-$ 507.

, H.V. Soule, H.L. Kyle, F. House and The NIMBUS-7 ERB Experiment Team, 1984a: The earth radiation budget (ERB) experiment, an overview. J. Geophys. Res., 89, No. D4, 5021-5038.

, R.J. Tighe and The NIMBUS-7 ERB Experiment Team, 1984b: The earth radiation budget derived from the NIMBUS-7 ERB experiment. $J$. Geophys. Res., 89, No. D4, 4997-5010.

Kubota, I. and H. Imai, 1986: On land-sea contrast in the earth radiation budget. Meteorological Satellite Center Technical Note, 13, 1-31.

Madrid, C.R., edt., 1978: The NIMBUS-7 user's guide. The Landsat/Nimbus Project, Goddard Space Flight Center, NASA, pp. 17.

Manabe, S., 1983: The theory of climate changes. Lecture note at Tokyo University.

Ohring, G. and P.F. Clapp, 1980: The effect of change in cloud amount on the net radiation at the top of the atmosphere. J. Atmos. Sci., 37, 447-454.

and A. Gruber, 1983: Satellite radiation observations and climate theory. Advances in Geophysics, 25, 237-304.

Raschke, E. and T.H. Vonder Haar, 1973: The annual radiation balance of the earth-atmosphere system during 1969-70 from Nimbus-3 measurements. J. Atmos. Sci., 30, 341-364.

Stephens, G.L., G.G. Campbell and T.H. Vonder Haar, 1981: Earth radiation budgets. J. Geophys. Res., 86, C10, 9739-9760.

Tighe, R.J. and M.Y.H. Shen, 1983: NIMBUS-7 science quality control program, ERB MATRIX data validation document. Systems and Applied Sciences Corporation, pp. 83 .

Warren, S.G. and S.L. Thompson, 1983: The climatological minimum in tropical outgoing infrared radiation, contributions of humidity and clouds. Quart. J.R. Met. Soc., 109, 169-185. 


\title{
地球放射収支の海陸差
}

\section{久保田 効}

\author{
気象衛星センター
}

\section{今井博子}

気争研究所

要 約

地球放射収支が海陸によっていかなる差異があるか明確にするため，NIMBUS 7 によって観測され た地球放射収支の月平均全球分布を FGGE 期間（1978，11一1979，10）について解析した。その結果次 のことが分った。

(1)正味の太陽放射束，正味の全放射束ともに東西平均をとると，太陽の赤緯を中心とする約 $70^{\circ}$ 緯度 巾にわたって陸上より海上で大きく，その差は約 $40^{\circ}$ 緯度巾にわたって $40 \mathrm{~W} / \mathrm{m}^{2}$ を越える。海と陸の晴 天アルベド差によって説明できる差はこの量の約半分で，残りの半分は海上と陸上での雲量の差に待た なければならない。正味の太陽放射束，雲量および青天アルべド間の関係式から見積ると，この差を生 じるには陸上の雲量が海上より13\%多くなければならない。量近の気候的な雲量分布罒によるとこの見 積りは赤道域に限り妥当である。

(2)一方 $60 \mathrm{~N}$ 又は $60 \mathrm{~S}$ を中とする高緯度では正味の太陽放射束は逆に海上より陸上で30。緯度巾にわ たって約 $15 \mathrm{~W} / \mathrm{m}^{2}$ 大きい。海と陸の晴天アルベド差は，上と同じ程度の逆の差を生じるはずなので，陸 上より多い海上の雲量が，アルベド差による効果を陵駕していなければならない。これを説明するため には海上の雲量が陸上より $17 \%$ 多くなければならない。最近の気候的な雲量分布図はこの見積りが妥当 であることを示している。

(3)正味の地球放射の緯度変化をみると，赤道付近にITCZに対応する極小，亚熱带に高圧带あるいは 下降域に対応する二つの極大がある。この極大，極小，極大といった緯度変化は海上より陸上で大きい。 つまり直接循環は海上より陸上で活発のように見える。 